\title{
Active Aging Policies between Individual Needs and Collective Goods. A Study of Active Aging Policies and Practices in Norway
}

1 Tove Midtsundstad'

Senior Researcher, Fafo Institute for Labour and Social Research, Norway

\section{Hanne Bogen}

Senior Researcher, Fafo Institute for Labour and Social Research, Norway

\begin{abstract}
A main objective of European governments is to reduce the number of early retirees, either by reforming pension systems or promoting active aging in working life. The importance of formulating a coherent personnel policy for all age groups is increasingly recognized by employers. However, there is still a lack of knowledge as how to strategically cope with an aging labor force. The aim of this article is to define and discuss a number of challenges arising from workplace-related active aging policies. We in particular discuss how an emphasis on economic incentives and gains ("senior goods") may give rise to unanticipated side effects for the employers as well as the employees. The article is based on results from two recent studies: one study examining six Norwegian municipalities with seemingly good practices in work-related old age policies, and another examining such policies in eight establishments in four different industries.
\end{abstract}

\section{KEY WORDS}

Active aging policy / case studies / early retirement / pro-retention programs / older workers / work place measures

\section{Background}

\begin{abstract}
he future of older workers has become an issue of major concern to European governments (OECD, 2013; 2006). To fulfill future demand for labor and to ensure that there is a large enough workforce to carry tomorrow's pensions and public services, it is important to keep older workers in employment for longer.

Internationally, researchers have long been concerned with active aging policies and practices, and several studies have been published under the auspices of EU (cf. Walker, 1997; Taylor, 2006), European trade Union Institute (ETUI) (Jepsen et al., 2002), and OECD (OECD, 2006, 2013). The focus so far has generally been on employers' attitudes toward older workers, age discrimination, and the need for attitude campaigns and lifelong learning. One exception is Finland, where the research has focused on the importance of employees' working capacity and good working environment (see, e.g., Ilmarinen \& Louhevaara eds., 1999; Sterdyniak, 2007).
\end{abstract}

\footnotetext{
${ }_{1}$ Tove Midtsundstad, Fafo Institute for Labour and Social Research, Box 2947 Tøyen, 0608 Oslo, Norway. E-mail: Tove.Midtsundstad@fafo.no
} 
Although the importance of formulating a coherent personnel policy for all age groups is increasingly recognized by employers, there is a lack of knowledge as how to strategically cope with an aging labor force (cf. Ennals \& Salomon, 2011; Loretto et al., 2009; Phillipson \& Smith, 2005; Taylor, 2006).

In two recent projects, we studied six Norwegian local governments and six public and private establishments with seemingly good merits in terms of work-related active aging policies and practices (Bogen \& Hilsen, 2013; Bogen \& Midtsundstad, 2007; Midtsundstad \& Bogen, 2011a). One of our aims was to clarify some of the choices and dilemmas that employers and local trade union leaders experienced as they formulated and implemented active aging policies. In particular, we wanted to investigate whether an emphasis on economic incentives gives rise to unanticipated side effects for employers as well as employees. We ask: Faced with different types of active ageing policy measures at the workplace level, which initiatives are chosen - and why?

Before presenting our findings, we briefly describe the Norwegian welfare and labor market context. Thereafter, we clarify what we mean by work-related active aging policies, and categorize different types of management initiatives aimed at strengthening the role of older workers. We also summarize earlier studies and findings and relevant theories to throw light on our research questions and findings.

\section{The Norwegian context}

In the autumn 2001, the Norwegian government and the social partners signed a tripartite agreement for a more Inclusive Working Life (the IW-agreement) aiming at reducing the number of workers leaving the labor market due to early retirement. ${ }^{1}$ The agreement attempted to redefine the responsibilities of the state, the employers, and the employees. It called for greater social responsibility by employers in order to reduce early retirement rates. All Norwegian enterprises (public and private) are encouraged to sign up as Inclusive Working Life enterprises on a voluntary basis. To become an IW-enterprise, the enterprise must sign an agreement with the local trade union and a representative from the state. This earns them certain comparative advantages in terms of state advice and financial support, though mainly advisory support. ${ }^{2}$

The Tripartite Agreement rests on the assumption that part of the solution to the problem of early retirement and labor market exclusion is to be found at the workplace level. However, the IW-agreement only offers a framework for the social dialogue at the workplace. It is thus pertinent to ask what employers, local trade unions, and shop stewards actually do to combat early retirement and promote longer working careers.

The IW-agreement covers about 50 percent of the workforce (Ose et al., 2009). In particular, the municipalities have shown commitment to meet the challenges of early retirement (ibid.). This engagement is most likely linked to the serious labor shortage that are expected in the coming years, mainly driven by a growing number of teachers approaching retirement age, as well as an expected increase in the need for staff in the health and care sectors (NOU, 2010: 13).

Policies aiming at keeping employees in work for longer are closely related to the early retirement schemes. Before 2011, old age pension in Norway under the National Statutory Insurance Scheme was not paid out prior to 67 years of age. ${ }^{3}$ The contractual 
early retirement scheme (AFP scheme), however, provided about $80 \%$ of workers above the age of 62 the opportunity to take an early retirement (Midtsundstad, 2004). AFP was initially launched in 1989, and from 1998, it allowed workers to retire with full, or partial, pension from the age of 62. In the public (state and municipal) sector, the scheme covers all employees and in the private sector about 45\% (ibid.). Before 2011, AFPbenefits in the private sector equaled the old age pension received from the National Insurance Scheme at the age of 67 , as well as a small contractual pension supplement. This is still the case in the public sector. However, between the age of 65 and 67, benefits in public sector are calculated in accordance with the occupational pension scheme. This has a guaranteed level ensuring all members with full qualification (30 years) a pension equivalent to two-thirds of their wage at the time of retirement ("gross arrangements"). ${ }^{4}$ The AFP-scheme prior to 2011 weakened the economic incentives for employees to remain in employment after the age of 62 , and still does so in the public sector. Employers also had some incentives to retain older workers as they partly or fully carry their own AFP-costs. The costs connected with employees retiring early through AFP were partly or fully born by the establishments until 2011 in the private sector. ${ }^{5}$

\section{Work-related old age policies}

Different personnel policy measures may be employed to increase recruitment and employment and enhance the retention of older workers. In this article, we study programs for the prevention of early retirement and retention of older workers in the workplace, and not recruitment policies as such. Prevention programs encompass long-term efforts aimed at ensuring that employees do not end up in a vulnerable situation. These initiatives converge to what may be called sustainable personnel policies and aims at preventing health injuries or loss of work capacity, competence, and motivation. These policies do, in most cases, target all employees, and not older workers exclusively (e.g., those above 62 years of age). Retention schemes, in contrast, are directly targeting workers who already are in a vulnerable position or for other reasons (e.g., desire for more leisure time) may wish to retire early. Initiatives for retention are directed toward defined target groups and particular situations. They are more often short term and narrow in scope compared with prevention programs (Midtsundstad, 2007). One example is how retention programs in Norway target employees around the age of 62, the age at which workers have the opportunity to retire early with AFP (and since 2011 also with old age pension from the National Insurance scheme).

Another distinction can be made between measures directed at the individual employee, with the aim to maintain or increase workers ability and motivation to work, and measures directed at the workplace or workplace environment, with an aim to improve working conditions for both individual employees and the workplace in general. In addition, some measures are traditional management tools that neither seek to change the individual nor the workplace. They include different types of welfare arrangements or benefits to facilitate a better work-life balance, as well as measures that aim to change the individual employee's preferences between work and leisure (ibid.).

In addition, we distinguish between measures offered to all employees over a certain age (universal or collective) and measures offered on the basis of individual assessment (means tested). 


\section{Previous research}

According to Karppinen (2008), companies that introduce active aging policies do so to avoid labor and skill scarcity, retain valuable experience and skills, provide good return on investments in training, and enhance work satisfaction, which may contribute to improve quality and productivity. The importance of these factors is supported by several other studies (cf. Cohen et al., 2009; Henkens, 2005; Midtsundstad, 2005, 2011; Taylor, 2006; van Dalen, 2011, 2010a, 2010b; Walker, 1997). A study by Taylor (2006) examined more than 100 organizations in different EU countries (EU15) that had been longstanding examples of good practice in old age management. This study found that in the period between mid-1990s and 2006, organizations started to approach old age policies in increasingly complex ways. There are several reasons for this development, but business performance and efforts to maintain competitive advantages were important reasons together with reducing costs, maintaining a skilled and competent workforce, and maintenance of labor supply in general. He also concluded that companies' engagement in active aging policies and practices varied over the business cycle.

Some studies also discuss how lack of resources, both budgets and staff, make it difficult for managers to implement initiatives for older workers, such as shorter working hours, easier work tasks, or time off for learning and training (cf. Midtsundstad \& Bogen, 2011a; Midtsundstad, 2011; Larsen \& Miiller, 2006; Taylor, 2006). Although an enterprise may have adopted an active aging policy, middle managers often play a key role in implementing these policies (Furunes, 2008). However, relatively few managers reflect on the urgency of the aging challenge (Taylor, 2006; van Dalen et al., 2011). Some studies on stereotypical attitudes toward older workers have suggested that employers are becoming more positive toward this age group (Solem 2008); however, a considerable proportion of managers still held negative and inaccurate stereotypes of older workers (Vickerstaff et al., 2009).

The social partners have traditionally not been concerned with age discrimination. For many decades, European early retirement schemes were mainly developed in the context of economic restructuring, and seen as a way to end a working career in a dignified manner. Although trade unions have often been ambiguous in questions related to aging, pursuing a mixture of strategies at different levels (Hutsebaut, 2003), they have often been caught in contradictions between micro and macro level strategies. It seems, however, that Norwegian and Nordic social partners are more aware of the problem of demographic change than partners in other European countries (Van Dalen et al., 2011). This awareness may have motivated them to react and take more actions, than other European countries. The strong ties between social partners and governments in the Nordic countries, that is, the Nordic model (cf. Dølvik, 2013; Hippe et al., 2007), may be a main reason for this. The "Nordic model" with its institutionalized cooperation between the social partners and a tradition for consensus is also an important background for understanding the implementation process of the IW-agreement at the local level, including the choice of different active aging measures.

Research has demonstrated that the likelihood of implementing workplace policies is linked to the attitudes of trade union leaders. A representative survey by Trygstad (2006) found that it was more common to adapt the workplace to individual needs, particularly for persons with a reduced working capacity, if trade union leaders had a positive stance on management-employee relations, and when employee involvement 
was common. A study of 17 Norwegian manufacturing firms with old age management practices (Hertzberg \& Skinnarland, 2007) also indicated that pro-retention programs and measures were more successful when based on a shared employer-employee dialogue as well as an active involvement from shop stewards, although such involvement was not common.

The IW-Agreement clearly signals a new direction in work-life policy, yet several studies indicate that attitudes at the local level have not changed significantly. According to Midtsundstad (2007), trade union leaders rarely were directly involved in designing their establishments' age management policy and practice in $17 \%$ of all Norwegian enterprises), and only in a very small minority of enterprises $(7 \%$ were the policies included in local collective agreements). Midtsundstad (2005) also found that strong local relations between the social partners had no impact on companies' willingness to retain older workers.

This same pattern has been found in qualitative studies (Hilsen \& Steinum, 2006; Olsen \& Vangstad, 2004). Trade union leaders interviewed found it difficult to influence the employer-employee dialogue, and as long as management behaved "decently," they saw no need to intervene. Trade union leaders defined their role as that of a watchdog, and not as a proactive instigator or a developer of new policies. The researchers concluded that as long as there was no fundamental conflict of interests, no lack of mutual trust between management and employees, or no significant changes proposed, trade union leaders were happy to leave questions of policy development to the management. Also, Danish research reports that union leaders frequently are unenthusiastic to initiatives to combat exclusion and to promote a more inclusive work place (Hohnen, 2002).

Relatively few age management systems and pro-retention programs are properly evaluated, and consequently most retention programs and measures in use are deduced from research studying the causes of early retirement, that is, the importance of different pull and push factors, the causes of age-related changes in work ability, and age stereotypes and ageism. The most common measures in use to combat early retirement, according to Taylor (2006), are training and career development, followed by flexible working hours, both increasing with length of service. Additionally, measures to promote health and general well-being, long-established priorities in the Nordic countries, particularly in Finland, also have become a growing focus in most EU countries, although in contrast there is now less focus on the recruitment of older workers (ibid.).

In Norway, the picture is somewhat different. In 2005, 60\% of all Norwegian establishments had introduced measures to enable persons with a reduced working capacity to continue in employment; $40 \%$ reported to have programs preventing health problems and improving work ability, whereas $34 \%$ of the establishments promoted training, life-long learning, and career development for older employees past the age of 55 (Midtsundstad, 2007). Similarly, 31\% reported to have pro-retention programs for older employees above the age of 62 (ibid.). I 2010 the picture was more or less unchanged (Midtsundstad \& Bogen, 2011a).

The most common initiatives offered to retain older workers in Norway are less strenuous work, rearrangement of work tasks, shorter working hours without a proportionate wage reduction, and provision of additional bonuses (ibid.). This was found to be the case in both 2005 and in 2010. However, we lack knowledge on how managers decide between different initiatives and measures, which programs and measures are the most commonly used, and why. 


\section{Data and methodology}

We conducted case studies in six $^{6}$ Norwegian municipalities ${ }^{7}$ in 2006-2007 (Bogen \& Midtsundstad, 2007) and in 2012 (Bogen \& Hilsen, 2013), covering in particular care work and teaching professions. In addition, we carried out case studies in eight different public and private establishments ${ }^{8}$ in the period between 2009 and 2010, covering different types of work activities and professions: low/semi-skilled industrial work, care work, high skilled engineering work, and executive officers' work in ministries or directorates (Midtsundstad \& Bogen, 2011a).

Our first sampling criterion was to include municipalities and establishments that had implemented an old age policy and introduced specific measures to prevent early retirement. A second criterion was that this policy had been running for some years in order to secure that it was well established in the enterprise. When sampling municipalities and firms, we had no knowledge of any possible effects of the old age policies that had been implemented. We also lacked a register of enterprises that had implemented an old age policy, so we consulted experts within the national organization of municipalities (KS), The Confederation of Norwegian Enterprise (NHO), the main employer organization (LO), and the Norwegian Labour and Welfare Organisation (NAV) in the sampling process. Through the two projects, we managed to sample $12^{9}$ different cases of establishments with a work-related old age policy.

In each establishment, we interviewed the personal manager, one to two middle managers, and and one to three trade union leaders. In addition, we had individual interviews with a sample of five to eight older employees and early retirees above the age of 58 in each establishment, who were either a) about to take the decision whether to retire or not, b) who had recently retired, or c) had continued working beyond the early retirement age (which is 62 years in Norway for most employees). We used semi-structured interviews and special interview guides for managers, trade union leaders, and older employees and early retirees, respectively. ${ }^{10}$ All interviews were transcribed.

This article is mainly based on data from interviews with managers and trade union leaders. In the presentation of findings, we focus on the types of measures offered and the programs established. We look especially at the characteristics of the chosen measures, and the reasoning behind selecting them. The latter will be discussed in more detail in order to identify reasons for why existing work-related old age policies in Norway do not seem to affect retirement behavior in the expected way, as some analyses indicate (i.e., Midtsundstad et al., 2012a, 2012b).

As our research design is based on case studies, our findings are not generalizable to all Norwegian establishments. However, our main purpose here is to investigate why these specific measures were selected, and what experiences enterprises thought to be in the forefront on old age policy had gained. Which possibilities and challenges are employers, trade union leaders, and employees facing when attempting to establish successful work-related old age policies? By scrutinizing municipalities and private firms that already had implemented an old age policy and introduced specific measures to prevent early retirement, we aim to reveal mechanisms that have a broader bearing beyond the specific units studied. We also discuss our findings in the light of earlier research. 


\section{Results from the case studies}

Reasons for early retirement vary both between individual employees and between different types of enterprises. A reasonable assumption is therefore that precautions taken at the enterprise level to avoid early retirement would vary accordingly. However, we found little such variation. All 12 establishments ${ }^{11}$ had a set of different measures (see Tab. 1), but they all offered some sort of financial compensation or extra time off as measures to reduce early retirement. These measures were in most cases given to all employees above a specific age (usually 62 years) and were viewed by most middle managers and employees as an individual right.

Table I An overview of the measures offered in the different establishments studied

\begin{tabular}{|c|c|c|c|c|}
\hline Case & Employees & $\begin{array}{l}\text { Active aging } \\
\text { measures from }\end{array}$ & $\begin{array}{l}\text { Financial remuneration and } \\
\text { reduced working hours' }\end{array}$ & Other measures \\
\hline Municipality I & 2800 & 2003 & $\begin{array}{l}\text { Employees who continue work- } \\
\text { ing after the age of } 62 \text { can select: } \\
\text { a reduction of hours worked } \\
\text { (20\%) without a parallel wage } \\
\text { reduction, or up to NOK } 25000 \\
\text { for various adaptive measures } \\
\text { (i.e., extra days off, no or less } \\
\text { weekend work). }\end{array}$ & $\begin{array}{l}\text { For all employees: performance } \\
\text { appraisals (annual), possibility } \\
\text { to a change in shifts, encour- } \\
\text { age career shifts, and lifelong } \\
\text { learning. }\end{array}$ \\
\hline Municipality 2 & 2000 & 2002 & $\begin{array}{l}\text { Employees who continue work- } \\
\text { ing after the age of } 62 \text { can select: } \\
\text { a wage increase (NOK } 12 \text { 000); } \\
\text { reduced working hours without } \\
\text { a parallel wage reduction (i.e., I0 } \\
\text { extra days off from age } 62,10 \% \\
\text { reduction in hours worked from } \\
\text { age } 63 \text { and } 20 \% \text { from age } 64 \text { ), } \\
\text { or NOK } 12000 \text { per year for } \\
\text { various adaptive measures. }\end{array}$ & $\begin{array}{l}\text { Basic computer training from } \\
\text { the age of 55, and performance } \\
\text { appraisal at age } 58 \text { (manda- } \\
\text { tory). }\end{array}$ \\
\hline Municipality 3 & 1200 & 2001 & $\begin{array}{l}\text { Employees who continue } \\
\text { working after the age of } 62 \text { get } \\
\text { an annual bonus (NOK } 12000 \text { ) } \\
\text { up to the age of } 65 \text {, or NOK } \\
\text { I0 } 000 \text { per year for various } \\
\text { adaptive measures (mainly for } \\
\text { extra leave). }\end{array}$ & \\
\hline Municipality 4 & 1500 & 2001 & $\begin{array}{l}\text { Employees who continue work- } \\
\text { ing after the age of } 62 \text { can select: } \\
\text { reduced working hours without } \\
\text { a wage reduction ( } 90 / 100) \text {, an } \\
\text { annual bonus (NOK I } 2000 \text { ), a } \\
\text { wage increase of NOK } 12000 \\
\text { (pensionable), or NOK } 10000 \\
\text { per year to pay for various adap- } \\
\text { tive measures. }\end{array}$ & $\begin{array}{l}\text { Performance appraisal bi- } \\
\text { annually from the age of } 55 \text { and } \\
\text { annual grants for special welfare } \\
\text { measures (collective). }\end{array}$ \\
\hline
\end{tabular}




\begin{tabular}{|c|c|c|c|c|}
\hline Case & Employees & $\begin{array}{l}\text { Active aging } \\
\text { measures from }\end{array}$ & $\begin{array}{l}\text { Financial remuneration and } \\
\text { reduced working hours I }\end{array}$ & Other measures \\
\hline Municipality 5 & 2300 & $2003^{2}$ & $\begin{array}{l}\text { Employees who continue } \\
\text { working after the age of } 62 \text { can } \\
\text { select: reduced working hours } \\
\text { ( } 10 \% \text { ) without a parallel wage } \\
\text { reduction, an annual bonus of } \\
\text { NOK I } 5000 \text { (up to the age of } \\
65 \text { ), or an annual wage increase } \\
\text { of NOK } 2500 \text { (pension- } \\
\text { able). They can also get up } \\
\text { to NOK } 10000 \text { per year for } \\
\text { various adaptive measures. }\end{array}$ & $\begin{array}{l}\text { Seminars for all older workers } \\
\text { at age } 60, \text { management course } \\
\text { in active aging, promotion of } \\
\text { late life career planning at age } \\
45+\text {, and measures to promote } \\
\text { lifelong learning. }\end{array}$ \\
\hline Municipality 6 & 800 & 2001 & $\begin{array}{l}\text { Employees who continue } \\
\text { working after the age of } \\
62 \text { can select: reduced } \\
\text { working hours without a } \\
\text { parallel wage reduction } \\
\text { (90/100), or a wage increase } \\
\text { (individual negotiations). }\end{array}$ & $\begin{array}{l}\text { Performance appraisal for all } \\
\text { older workers, promotion of } \\
\text { lifelong learning for all past } \\
55 \text { years of age, and various } \\
\text { adaptive measures. }\end{array}$ \\
\hline $\begin{array}{l}\text { Governmen- } \\
\text { tal sector } \\
\text { (ministry) }\end{array}$ & Ca. 150 & 2005 & $\begin{array}{l}\text { All governmental employees } \\
\text { past the age of } 62 \text { have (from } \\
2008 \text { ) the right to } 8 \text { additional } \\
\text { days of annual leave (regulated } \\
\text { by collective agreements). In } \\
\text { addition, the employees in this } \\
\text { establishment get an additional } \\
6 \text { days of annual leave from } \\
\text { the same age (regulated by the } \\
\text { local collective agreement). }\end{array}$ & $\begin{array}{l}\text { Those who to retire either fully } \\
\text { or partly with AFP-pension } \\
\text { have the opportunity to return } \\
\text { to fulltime work after I year } \\
\text { if they regret their decision. } \\
\text { Those who need it may also } \\
\text { change their ordinary work } \\
\text { tasks. }\end{array}$ \\
\hline $\begin{array}{l}\text { Governmen- } \\
\text { tal sector } \\
\text { (directorate) }\end{array}$ & Ca. 250 & 2005 & $\begin{array}{l}\text { All governmental employees } \\
\text { past the age of } 62 \text { have (from } \\
\text { 2008) the right to } 8 \text { additional } \\
\text { days of annual leave (regulated } \\
\text { by collective agreements). In } \\
\text { addition, the employees in this } \\
\text { establishment get an additional } \\
6 \text { days of annual leave from } \\
\text { the same age (regulated by the } \\
\text { local collective agreement). }\end{array}$ & $\begin{array}{l}\text { The opportunity to give older } \\
\text { employees with expert compe- } \\
\text { tence a wage increase, time off } \\
\text { with or without compensation, } \\
\text { reduced working hours over a } \\
\text { shorter period, the possibility } \\
\text { to work from home, and/or } \\
\text { the possibility to join different } \\
\text { courses and seminars. Top man- } \\
\text { agers also have the opportunity } \\
\text { to shift from management to } \\
\text { operative service, retaining } \\
\text { their wage level. }\end{array}$ \\
\hline $\begin{array}{l}\text { Private } \\
\text { engineering } \\
\text { firm (road } \\
\text { construction) }\end{array}$ & 1000 & 2005 & $\begin{array}{l}\text { Employees who continue } \\
\text { working after the age of } 62 \\
\text { can get up to } 6 \text { weeks extra } \\
\text { of annual leave off with full } \\
\text { compensation. }\end{array}$ & \\
\hline
\end{tabular}




\begin{tabular}{|c|c|c|c|c|}
\hline $\begin{array}{l}\text { Private } \\
\text { engineering } \\
\text { firm (energy } \\
\text { supply) }\end{array}$ & 250 & 2006 & $\begin{array}{l}\text { Employees who continue } \\
\text { working after the age of } 62 \text { can } \\
\text { either select reduced working } \\
\text { hours without a parallel wage } \\
\text { reduction or get a special } \\
\text { senior wage increase. }\end{array}$ & $\begin{array}{l}\text { Special seminar arranged an- } \\
\text { nually for } 55+\text { s to encourage } \\
\text { them to prolong their working } \\
\text { careers (beyond } 62 \text { years). Man- } \\
\text { agers also have the opportunity } \\
\text { to shift to an expert position. } \\
\text { Top managers also have the } \\
\text { opportunity to shift from man- } \\
\text { agement to operative service, } \\
\text { retaining their wage level. }\end{array}$ \\
\hline
\end{tabular}

\begin{tabular}{ll}
\hline $\begin{array}{l}\text { Private } \\
\text { industry } \\
\text { (process) }\end{array}$ & Employees who continue Have changed the normal shift \\
& working after the age of 62 get plan from four to three shifts. \\
& I week additional annual leave. \\
& In addition, those who work \\
& the normal shift plan and have \\
& worked in the company for \\
& more than 25 years, or have \\
& pasted the age of 55, get an \\
& additional week annual leave \\
& (regulated in the local collective \\
& agreement). \\
\hline
\end{tabular}

\begin{tabular}{llll}
\hline $\begin{array}{l}\text { Private } \\
\text { industry }\end{array}$ & II50 2005 & $\begin{array}{l}\text { Employees who continue } \\
\text { (installation) }\end{array}$ & $\begin{array}{l}\text { The possibility to combine par- } \\
\text { working after the age of } 62\end{array}$ \\
& tial AFP-pension with part time \\
& of annual leave or reduced & appraisal for older workers, and \\
& working hours without a paral- & special seminar to encourage \\
& lel wage reduction (80/90 or & older workers to prolong their \\
$90 / 100)$. & working careers. \\
\hline
\end{tabular}

I The extra days or weeks of annual leave granted to older workers are awarded on top of the 5 weeks and I day of annual leave, regulated by the Norwegian Holiday Act ( $\$ 5)$. In addition many Norwegian employees have another 4 extra day days off, regulated by collective agreements (i.e. a total of 6 weeks).

2 They started to work with active aging policy already in 1997.

${ }^{3}$ The collective agreement only gives older worker the possibility, not the right, to draw a partial AFP-pension.

Previous surveys have found that among older workers in Norway bonuses, wage increases and reductions in working hours are the most favored measures to prolong working careers (Hippe et al., 2012). Surveys also demonstrate that Norwegian leaders believe that economic incentives, like bonuses, and reduced working hours are the best measures to postpone early retirement (see, e.g., Furunes, 2008; Midtsundstad \& Bogen, 2011a; Midtsundstad, 2007). Our studies confirmed these findings. Both leaders and employees seemed to prefer economic measures and additional annual leave, as opposed to work adjustment measures. However, they stated different reasons for this preference: leaders preferred these measures as they appeared less time-consuming for them, as they did not have to rearrange the organization of the work by adjusting work tasks. Employees preferred these measures because both extra money and extra leave appeared as more welcomed and neutral "goods" than work adjustments, and more in line with ordinary negotiated arrangements. 
The interviewed managers frequently recommended that old age measures were to be offered on the basis of an individual needs assessment, not as a universal good, distributed to all above a certain age. However, such assessments were rarely carried out. The main reasons seems to be that universal, rather than individual means tested measures more easily gained acceptance among employees and trade union leaders because it seemed fair, and among management because a distribution of measures according to evaluation of individual needs could cause an unfavorable work climate. Hence, our case studies showed that most measures introduced were directed indiscriminately toward all employees above a certain age limit, not just at particular groups with an especially strenuous work situation or high risks for early retirement. Hence, the initiatives were based on an equal treatment philosophy. As a manager and a union leader put it:

"The measures we offer were not intended to be automatically distributed to all regardless of situation. But it is hard to find a good and just way to distribute them so in practice all above the age of 62 are entitled to our old age measures." (leader in a public establishment 2012)

"It is hard to find an acceptable way to distribute measures when you differentiate measures between employees. What criteria should be used?” (union leader in a private establishment 2010)

We also noted that employees were usually allowed to decide themselves which measures to select even though leaders intended to have a say in this decision process. As one manager explained:

"I think it is most fair that employees decide themselves what measures to select according to their own needs and private situation. Some may need the extra money because they have earned too little or have a modest pension, others may want more time off for different reasons." (manager in a private establishment 2010)

As mentioned, evaluation of individual needs and individually adjusted measures was often regarded as time-consuming by middle managers and would require both personal involvement and planning on behalf of the manager. As one manager put it:

"It takes a lot of time to guide each person so that he or she can find what I as a leader think would be the appropriate measure for each person and too often we lack that extra time. And I don't want to intrude too much into those persons' private reasons for choosing the way he or she does." (manager in a public establishment 2010)

Hence, collectively held values about justice and fairness clearly prevailed between mangers, union leaders, and employees. We also experienced that the notions of justness and fairness were based on ideas of sameness, that is, the more equal the workload or work performance or benefits, the more it was regarded as just and fair. These norms seem to influence both the type of measure offered by the employer and, most of all, the way they were distributed, that is, offered by middle managers and actually selected by employees (Midtsundstad \& Bogen, 2011c).

These values also seemed to include the younger generations of employees, as they rarely expressed criticism toward the senior arrangements. As an effect of a general trust 
between generations in Norwegian working life, younger generations normally benefit from other types of "goods," for example, connected to family life and bringing up children. As one of our younger interviewees expressed it:

"Sooner or later we will be in the same situation as our older colleagues, needing special arrangements to prolong our working carrier." (young union leader in a public establishment 2010)

The older generations of employees, on the contrary, rarely expressed any concern about putting a heavier work load on to their younger colleagues in their selection of measures and this was not the reason for choosing financial remunerations and reduced working hours rather than work task adjustments. The selection of measures was to a larger extent a worry for mangers, as they would in the end be responsible for reorganizing the work process and find substitutes and suitable work task for those who were in need of adjustments. Besides, some of the younger employees may also have health problems and need adjustment.

In the following section, we will discuss more thoroughly some aspects and dilemmas characterizing the selected measures. We will also draw attention to some of the dilemmas of introducing active aging policies.

\section{Preferences of financial remuneration and reduced working hours}

As previously mentioned, most of the establishments studied provided financial remuneration to employees who stayed in employment above the age of 62 (Tab. 1). Employees who receive financial remuneration (or any type of measures) as part of a work-related old age policy agree to stay in their job, for example, one additional year, as this is the precondition for receiving these measures. As such, the measures have an effect, although only to the extent that the employee was determined to retire. If not, one could say that the measures were superfluous as the employee was likely to stay in employment, regardless of any measures offered.

The assumption behind the measures (e.g., increased pay, bonus, or severance pay) is that financial incentives motivate the employee to prolong her/his occupational career. However, this will only be true if it is lack of motivation that constitutes the problem, rather than bad working conditions, health problems, or reduced working ability. Studies have found that unmotivated employees prefer more positive attention from the employer rather than reduced working hours or increased pay to continue working (Hilsen \& Steinum, 2006; Hilsen, 2009). Thus, if employers put more effort into convincing workers that they are both wanted and needed, they may motivate workers to postpone retirement. Such attitude changes are normally much less costly, not to say free, than increased pay and bonuses, but may require some engagement on behalf of the middle manager. On the contrary, generous schemes, offering bonuses, and reduced working hours without proportionate pay reduction may also in itself signal that the seniors are appreciated at the workplace. An older worker explained:

"Extra money or reduced working hours is important for me since it signals that my leader still value what I am doing, especially the extra money since I reached the top of my pay scale long ago." (older worker in public establishment 2009) 
An important challenge concerning economic incentives is that they may prove paralyzing, in the sense that employers do not have to take actions to deal with other causes of early retirement, for example, by creating a better and more inclusive working environment (preventive measures).

Also, reduced working hours without a parallel pay reduction as a measure for postponing retirement may represent an economic incentive for employees, compared with a situation without compensation. However, a reduction in working hours may also be classified as a work adjustment measure, as it eases the workload and enhances the employee's possibility to recover as working hours are reduced. It may then be preferred by employers and employees, not only because it represents an economic incentive but also because it promotes health and general well-being, without demanding adjustments of work tasks and extensive planning, apart from rearrangement of work schemes and, if necessary, a supply of substitutes. Compensated reduction of working hours may thus both be seen as an economic incentive and an easy way to change the work load.

Many health and social sector employees seem to prefer financial remuneration to reduced working hours, despite the fact that, as noted, the latter more likely will improve their work situation, as they are then less exposed to strenuous working conditions relative to the reduction of hours worked. The reason for choosing financial remuneration may be that they are low paid and/or have not yet acquired the 30 years in service required for entitlement to a full occupational pension benefit. Another reason, especially in the health and care sector, may be that most of the employees already have a part-time job, either because it is difficult to get a full-time job or because they have themselves chosen to work part time (Nergaard, 2010). However, some of the older nurses and nurse assistances interviewed claimed that they, if they were given the choice, would prefer less strenuous shifts (e.g., avoiding evening shifts followed by morning shifts) instead of bonuses and reduced working hours. This suggests that municipalities should more thoroughly examine the effects of various measures in light of the needs and actual work situations of different occupations and individuals.

The focus on economic incentives may also be related to lack of economic incentives on behalf of the employees in the AFP schemes in the public sector (and before 2011 in the private sector too), as they give the employees the same pension benefit whether they retired at the age of 62 or 66 . Bonuses and wage increases will then compensate for this lack of economic incentives.

It may also be the case that trade unions and union leaders prefer economic incentives including reduced working hours without wage reduction, because they transfer their traditional concern with wages and working hours into new areas, such as old age policies. It may seem easier for shop stewards to demand wage increases, bonuses, and reduced working hours for all older workers (pasted 62), than to demand older workers a right to individual, adjusted measures, which in each case will be evaluated by management. The same goes for control and follow up of measures that have already been agreed. As mentioned earlier, other studies have found that trade unions mostly got involved in issues covered by the collective agreement, such as wages and working time, including shift work (Hertzberg \& Skinnarland, 2007).

Knowing that employees in other municipalities gain benefits like extra pay or reduced working hours without parallel wage reductions may also influence the trade unions to demand similar benefits at their own work place, as we found to be the case in some of the establishments studied. This spillover effect may also indicate that union 
leaders to some degree have lost the focus on the original goal of counteracting early retirement. Instead, they focus on their main job, which is to struggle for more fringe benefits and social benefits for their members, which in this case are those above a certain age.

\section{Universal or targeted measures?}

As noted, most establishments in our studies aim at integrating age management and measures into the general personnel strategy. This means that any individual assessment should be carried out jointly by the manager and the employee, to find the type of measures best suited for each employee.

Most establishments in our studies pursued universal measures (cf. Tab. 1). All employees aged 62 or above were entitled to one or more measures, such as reduced working hours with full pay compensation, or pay increase/severance pay. Thus, measures distributed on the basis of individual needs were turned into common rights. In other words, employers too seem reluctant to discriminate between employees, as this would challenge a strong tradition of equal rights in Norwegian working life. One of the interviewed leaders said:

"Our employees do not tolerate unequal treatment." (manager in a private establishment 2010)

In spite of an intention to tailor means to individual needs, it is easier to grant everybody the same rights. Such equality of access to measures also has other advantages. It prevents unfair treatment of employees and counteracts a deterioration of the internal work environment. But this principle of non-discrimination makes it on the contrary difficult to regard the measures as an integrated part of the employer's personnel strategy. Thus, the employer may fail to actively abolish the causes of early retirement. Instead, measures are introduced, although no real commitment is made to tackle the causes behind why employees want to retire early.

In addition, universal measures are practical and may, from the employee's point of view, seem to be a fair strategy. It seems, however, that other measures would have been more suitable to some groups of employees, as the reasons for early retirement differ considerably between different groups of employees (cf. Bråthen \& Bakken, 2013; Midtsundstad, 2002, 2012; Phillipson \& Smith, 2005). Still, measures such as pay increase/ severance pay or a reduction in working time in return for full pay have broad support. Those are the measures preferred by most employees as they appear like an "offer you cannot refuse."

There are good arguments in favor of providing universal measures for all employees above a certain age. However, these universal arrangements may prove unnecessary costly, as they will be provided to employees who probably would have continued working even without any measures offered. The costs of providing universal measures may therefore, in particular if being generous exceed any potential cost-savings resulting from a reduction in early retirement. Counted in hours worked, the total number of hours reduced may exceed the number of hours gained by delayed retirement. This will particularly be the case in enterprises where few of the employees actually retired at the 
age of 62 before any retention program was introduced. This was the case in some of the establishments we studied, especially the ministry and the directorate and the two engineering firms. This outcome was also found in a study by Becken (2012) who evaluated the experiment with reduced working hours for older workers in some governmental sectors. It is thus important that the enterprises concerned have sufficient knowledge of and access to data displaying early retirement patterns and pension utilization within the organization, before they implement such measures, in order for them to estimate the actual costs and benefits connected with different measures. However, such data and cost estimations were generally missing in the enterprises we studied.

Access not only to retirement and pension data, but also to information on general economic performance, seems crucial. By our second visit to the six municipalities, the majority were, for different reasons, in deep economic hardship. Hence, several of the municipalities either abolished or wanted to abolish their most costly measures, such as bonuses and reduced working hours without parallel wage reductions. Some of the municipalities who wished to abolish these measures felt trapped, fearing the reaction from trade unions and employees. This is a real risk, as in a recent court case between a Norwegian municipality and the local trade union, the decision fell in favor of keeping these measures (Kommunal Rapport, 2013). This goes to show that taking something away from somebody often has a stronger motivational impact on their (here: employee's) behavior than adding something (Kahneman, 2011). Thus, removing measures may generate an unanticipated and negative signal effect, and lead to disappointment among older employees, who may feel that they are no longer appreciated by their employers.

\section{Organizational constrains}

In the case studies, we also found that considerations among colleagues in many cases were decisive to which measures the establishment decided to implement. In industrial sectors, with many parallel and dependent work processes, it also turned out to be particularly challenging to adapt work processes to individual needs. Such "tight" production processes often lack alternative tasks, odd jobs, and flexible working arrangements. In work processes where job rotation is a normal procedure, reduction of workload for one or two may also increase the load for the remaining work team, jeopardizing the health of even more employees. One reason, mentioned by a trade union leader, was the lack of a part-time culture in the industrial sector; most employees wanted to work full time until the day they retired.

"Easier work tasks would have been more suitable for many older workers, than a few extra days off, but we do not have enough such jobs available. Furthermore, it has to be real tasks we offer them. It is little tolerance for 'odd jobs."' (manager in a private establishment 2010)

In this establishment, we found that collective solutions (for all employees) rather than individual solutions were sought when trying to improve working conditions (changing the shift plan), because it was considered easier to both organize and achieve acceptance for such solutions among the remaining employees. The preference of collective solu- 
tions or measures, especially in male-dominated establishments, may also have a cultural explanation:

"Many workers find it difficult to talk about their needs for adjusted tasks and work. They do not want to talk about their health problems or difficulties." (union leader in a private establishment 2010)

A Danish study, cited in Jørgensen et al. (2006), indicated some of the same pattern even for a sample of government agencies. This study emphasized that unless sufficient substitute labor is provided, the senior workers are less likely to take the offer of reduced working hours because their workload will just pile up, generating a heavier workload that have to be dealt with later. Alternatively, they fear negative reactions from their colleagues if their workload increases as a result.

\section{Power and resources at the appropriate level}

Middle management knows individual employees better than top management. They have daily personnel responsibilities, and can therefore better judge the measures that may be most suitable for each individual, and also which measures that are possible to implement. In the establishments studied, middle managers were the ones that mostly mapped out the needs of older workers and suggest suitable measures.

However, some of the available measures proved difficult to implement. One reason was that funds were not set aside for substitute employees. For employees in two of the occupations studied, teachers, and care workers, absence from work was difficult without substitutes. Unlike administrative or technical employees, they were constantly in direct contact with end users such as pupils and nursing home residents. This is why funds for substitutes must be available if reduced working hours are to have the desired effects. The same conclusions emerge in other studies of senior policy practice at the enterprise level (cf. Larsen and Miiller, 2006).

Furthermore, we found that savings due to reduced early retirement often went to the central part of the organization. If one local unit of the organization succeeded in reducing the retirement rate, savings were not allocated back to their unit of origin. This may reduce motivation among middle management and employees alike for retirement reduction than if the successful units were allowed to keep some of the savings. Some public establishments are contemplating the transfer of responsibility for the AFP to the local units, so that they themselves carry most of the costs of the scheme. Correspondingly, they will also keep (parts of) the savings generated by a reduction in AFP-departures. This arrangement is expected to strengthen the support of old age policies within the organization, especially among middle management in the public sector.

\section{Conclusion}

Work-related active aging policies in Norway are to a large extent characterized by a consensus between employers and employees on the measures offered. Furthermore, there is a focus on measures to retain workers who are entitled to early retirement benefits (age 62 and above), rather than measures to prevent early retirement in general 
(OECD, 2013). As our case studies demonstrate, employers, as well as union leaders and employees, seem to prefer economic measures to prevent early retirement, like bonuses and reduction of working hours without a proportionate wage reduction, rather than measures to improve the working environment or increase the employees' working ability. Measures are most frequently distributed universally, to all old employees, regardless of individual needs. Our findings also indicate that the presence of economic incentives often overshadow use of other, noneconomic, and adaptive measures.

One of the main reasons for early retirement among employees in Norway is health problems and heavy workloads (Midtsundstad, 2002, 2005, 2012). The shared acceptance of economic incentives may therefore explain the lacking effects of workplacerelated measures (Becken, 2012; Midtsundstad et al., 2012a, 2012b). Last, although the Norwegian IW-agreement recommends the use of individual mean tested measures to prevent early retirement, and also top managements seem to prefer them, most of the establishments fronting old age policies in Norway have chosen universal measures.

The main reasons for selecting economic and universal, instead of means-tested and noneconomic measures, seem to be an uncritical imitation of other establishments' policies, strong collectively held values of sameness, and 'equal rights for all' in Norwegian working life, organizational constrains, and, to some extent, middle managers lack of time, resources, and economic incentives to prioritize individual needs assessments.

Research has shown that the causes of early retirement are complex and are generated by a number of different factors within, as well as, outside the workplace (Midtsundstad, 2012). The various pull and push factors also vary in importance for different professions and educational groups (ibid.). One would therefore assume that in order to be effective, the initiatives and instruments launched to prevent early retirement need to vary between professions, industries, and sectors. In Norway today, however, they do not. The options and the allocation criteria are surprisingly similar across industries and enterprises, despite the heterogeneity of needs, problems, and challenges. This may be one reason why active aging policies and the measures chosen by Norwegian establishments are not necessarily effective in reducing early retirement.

In addition, the costs of the measures offered may exceed the intended gains, as those who would continue working anyway also are entitled to the senior measures. The same argument goes for labor supply, that is, whether there will be any additional hours worked or not, as many of those who would otherwise work full-time now choose to work part-time.

An additional problem is that few of the establishments with an implemented old age policy have actually evaluated the effects of this policy on retirement behavior. This is mainly due to lack of necessary data and knowledge on how to carry out such evaluations. An uncritical imitation of what is assumed to be good practice in terms of old age policies may then, at worst, lead to an unintended reproduction of ineffective and costly tools and measures.

\section{Financial support}

The projects were financed by Norwegian Research Council, FARVE - forsøksmidler arbeid og velferd, The Norwegian Association of Local and Regional Authorities (KS) and Unio. 


\section{References}

Becken, L. E. (2012) 'Seniortiltak og pensjoneringsadferd for seniorer med rett til AFP i statlig sektor' [Active ageing measures and retirement behavior among older workers entitle to an AFP-pension in governmental sector]. Søkelys på arbeidslivet 29(4): 349-367.

Bogen, H. \& Midtsundstad, T. (2007) Noen år til? Erfaringer med seniorpolitikk i seks kommuner. [Some more years? Experiences with active ageing policy in six different municipalities]. Fafo-rapport 2007:28. Oslo: Fafo.

Bråten, M. \& Bakken, F. (2012) 'Seniorer i arbeidslivet - hva påvirker beslutningen om å fortsette $\mathrm{i}$ jobb? [Older workers in employment - why do they prolong their working careers?]. Arbeid og velferd 2012(3): 38-48.

Conen, W. S., Henkens, K. \& Schippers, J. (2012) 'Employers' attitudes and actions towards the extension of working lives in Europe', International Journal of Manpower 33(6): 648-665.

Conen, W. S., Henkens, K. \& Schippers, J. (2011) 'Are employers changing their behavior towards older workers? An analysis of employers' survey 2000-2009', Journal of Ageing \& Social Policy 23(2): 141-158.

Dølvik, J. E. (2013) Grunnpilarene i de nordiske modellene. Et tilbakeblikk påarbeidslivs- og velferdsregimenes utvikling. [Cornerstones in the Nordic model]. NordMod 2030. Delrapport 1. Fafo-rapport 2013:13. Oslo: Fafo.

Ennals, R. \& Salomon, R. (eds.) (2011) Older worker in a sustainable society 21. Frankfurt am Main: Peter Lang.

Furunes, T. (2008) Managing older workers. Perception, attitudes, discriminatory Intensions, and decision latitudes. PhD Thesis UiS no. 53 - June 2008. Stavanger: Faculty of Social Science. Norwegian School of Hotel Management.

Hertzberg, D. \& S. Skinnarland (2007) Too old to rock'n roll? Fafo-rapport 2007:06. Oslo: Fafo.

Henkens, K. (2005) Stereotyping older workers and retirement: the managers' point of view», Canadian Journal of Ageing 24(4): 353-366.

Hippe, J., Midtsundstad, T. \& Veland, G. (2007) 'Dit ingen trodde man skulle'. [Where no one thought it would end]. In: Dølvik, J. E. et al. (red.) Hamskifte. Den norske modellen $i$ endring. Oslo: Gyldendal Akademisk.

Hilsen, A. I. \& Steinum, T. (2006) Fortell meg at jeg er ønsket! Sluttrapport fra Livsfaseprosjektet $i$ trygdeetaten, et prosjekt under Nasjonalt krafttak for seniorpolitikk i arbeidslivet. [Tell me that you need me?]. Rapport no. 2/2006. Oslo: Arbeidsforskningsinstituttet.

Hohnen, P. (2002a) Aftalebaserede skanejob. En kvalitativ analyse. Easy jobs regulated by collective agreements. A qualitative analyzes. Rapport 02:30. København: SFI - Det national forskningscenter for velfærd.

Hutsebaut, M. (2003) 'Social protection in Europe: a European Trade Union perspective', International Social Security Review 56(1): 53-74.

Ilmarinen, J. \& Louhevaara (eds.) (1999) FinnAge - respect for the Ageing: Action programme to promote health, work ability and well-being of ageing workers in 1990-96. People and work - research reports 26. Helsinki: Finnish Institute of Occupational Health.

Jepsen, M., Foden, D. \& Hutsebaut, M. (eds.) (2002) Active strategies for olders workers in the European Union. Brussel: European Trade Union Institute.

Jørgensen, M. S., Larsen, M. \& Rosenstock, M. (2005) Et lengre arbejdsliv. Tilbagetrekningsordninger og arbejdspladsens muligheder. [A longer working life. Early retirement schemes and enterprises' possibilities]. Rapport 05:03. København: SFI-Det nationale forskningscenter for velfærd.

Kahneman, D. (2011) Thinking fast and slow. New York: Farrar, Straus and Giroux (FSG).

Karppinen, J. (2008) Company measures for retention and reintegration of workers at risk of exclusion: European experience with older workers. In: Paper No. 9/2008. Dublin: European Foundation for the Improvement of Living and Working Conditions. 
Kommunal Rapport (2013) Tapte rettssak mot seniorer. [Lost lawsuit against senior workers] 20.3.13.

Larsen, M. \& Mølgaard Miiller, M. (2006) Rekruttering og fastholdelse af personer over 50 år. En kvalitativ undersøgelse på arbejdssteder. [Recruitment and retention of older workers past 50. A qualitative study of workplaces]. Forskningsafdelingen for beskæftigelse og erhverv. Arbejdspapir 04: 2006. København: SFI-Det nationale forskningscenter for velfærd.

Loretto, W., Vickerstaff, S. \& White, P. (2009) Introduction. In Loretto, W., Vickerstaff, S. and White, P. (eds.), The future for older workers. New perspectives. Bristol: The Policy press, University of Bristol.

Midtsundstad, T. (2012) «Pengene eller livet?» Eldres arbeidsmotivasjon og yrkesdeltakelse» [Employment and motivation for work among older employees]. In: S. Stjernø \& E. Øverbye (red.), Arbeidslinja. Arbeidsmotivasjonen og velferdsstaten. Oslo: Universitetsforlaget.

Midtsundstad, T. (2011) Inclusive workplaces and older employees: an analysis of companies' investment in retaining senior workers. The International Journal of Human Resource Management, 22(6), 1276-1292.

Midtsundstad, T. (2007) Fra utstøting til inkludering? En kartlegging av norske virksomheters arbeidskraftsstrategier overfor eldre arbeidstakere. [From exclusion to inclusion? Analysis of employers labour force strategies towards older workers]. Report 2007:37. Oslo: Fafo.

Midtsundstad, T. (2005) Virksomheters sosiale ansvar [Companies social responsibility]. In H. Torp (red.), Nytt arbeidsliv. Medvirkning, inkludering og belønning. Oslo: Gyldendal Akademiske.

Midtsundstad, T. (2004) Hvor mange har rett til AFP? [How many are covered by the AFP Scheme?]. Working paper 2004:04. Oslo: Fafo.

Midtsundstad, T. (2002) AFP-pensjonisten: Sliten - eller frisk og arbeidsfør. Analyse av førtidspensjonering og bruk av AFP $i$ LO-NHO-området [Early-retirees: Burned out - or bealthy and capable of working. Analyses of early exit from private sector companies in Norway]. Report 385. Oslo: Fafo.

Midtsundstad, T. \& Bogen, H. (2011a) Ulikt arbeid - ulike behov. Seniorpolitisk praksis i norsk arbeidsliv. [Different work - different needs? Active ageing policy and practice in Norwegian work-life]. Fafo-rapport 2011:10. Oslo: Fafo.

Midtsundstad, T. \& Bogen, H. (2011b) Seniorpolitikk - behov for justering? Analyse av praksis i seks foregangskommuner. [Active ageing policy - need for adjustments? Analyze of practice in six municipalities]. Søkelys på arbeidslivet 28(1-2): 89-106.

Midtsundstad, T. \& Bogen, H. (2011c) How the Worker Collective may Moderate Active Ageing Policy and its Outcomes, in R. Ennals \& R. Salomon (eds.), "Older Worker in a sustainable society", Labour, Education \& Society, vol. 21: 117-129. Frankfurt am Main: Peter Lang Verlag.

Midtsundstad, T. Hermansen, A. \& Nielsen, R. A. (2012a) Effects of companies' initiatives to reduce early retirement among older workers Nordic Journal of Working Life Studies 2(3): 89-108.

Midtsundstad, T., Nielsen, R. A. \& Hermansen, Å. (2012b) Tilrettelegging og seniortiltak påvirker det kommuneansattes sykefravær og tidligpensjonering? [The effects of active ageing policy on sickness absence and early retirement in the municipalities]. Søkelys på arbeidslivet 29(1-2): 140-150.

Nergaard, K. (2010) Avtalt arbeidstid og arbeidstidsønsker blant deltidsansatte. Arbeidskraftundersøkelsene 2008 og 2009. [ Actual and preferred work time arrangements among part-time employees]. Fafo-notat 2010:17. Oslo: Fafo.

NOU 2010: 13 Arbeid for helse. Sykefraver og utstøting $i$ helse- og omsorgssektoren. [Work as a measure to improve health. Sickness absence and exclusion in the health and care sector]. 
OECD (2013) Ageing and Employment Policies: Norway 2013. Working better with age. Paris: OECD.

OECD (2006) Live longer, Work Longer. Ageing and Employment policies. Paris: OECD.

Olsen, T. S. \& Vangstad, V. (2004) Inkluderende Arbeidsliv - for hvem? [An inclusive working life - for whom?]. Kristiansand: Trygdeetatens Arbeidslivssenter i Vest-Agder

Ose, S. O., Bjerkan, A. M., Pettersen, I., Hem, K.-G., Johnsen, A., Lippestad, J., Paulsen, B., Mo, T. O. \& Saksvik, P. Ø. (2009) Evaluering av IA-avtalen (2001-2009). [Evaluation of the IW-agreement 2001-2009]. June 2009. Trondheim: SINTEF.

Phillipson, C. \& Smith, A. (2005) Extending working life: A review of the research literature. Research Report No. 299. Leeds: Department for Work and Pension.

Solem, P. E. (2008) Endringer i ledernes holdninger til eldre arbeidskraft. [Changes in managers attitudes toward older workers]. Report no. 12/2008. Oslo: NOVA.

Sterdyniak, H. (2007) Finland 2007. Active Ageing Strategies to Strengthen Social Inclusion. Synthesis Report. Peer review, Helsinki 22.-23. November 2007.

Taylor, P. (2006) Employment initiatives for an ageing workforce in the EU15. Dublin: European Foundation for the Improvement of Living and Working Conditions.

Trygstad, S. (2006) Sykefraver og sosialt ansvar. [Absence due to illness and Corporate social responsibility]. Fafo-rapport 542. Oslo: Fafo.

Van Dalen, H. P., Henkens, K. \& Schippers, J. (2011) Dealing with older workers in Europe: a comparative survey of employers' attitudes and actions, Journal of European Social Policy 19(1): 47-60.

Van Dalen, H. P., Henkens, K. \& Schippers, J. (2010) Productivity of Older Workers: perceptions of Employers and Employees, Polpulation and Development Review 36(2): 309-330.

Van Dalen, H. P., Henkens, K., Henderikse, W. \& Schippers, J. (2010) Do European employers support later retirement?, International Journal of Manpower 31 (3): 360-373.

Vickerstaff, S., Loretto, W. \& Whith, P. (2009) The future of older workers: opportunities and constraints, In Loretto, W., Vickerstaff, S. \& White, P. J. (eds.) The future of older workers. Bristol: Policy Press.

Walker, A. (1997) Combating age barriers in employment. European Research Report. Luxembourg: Office for Official Publications of the European Communities.

\section{End notes}

1 The parties to the IW-Agreement defined the following three objectives: (a) To reduce sickness absence by at least $20 \%$ within 4 years, (b) to secure employment for a larger number of disabled people, and (c) to raise the de facto retirement age. This third objective is the subject of our investigation in this article. The state and the social partners have recently agreed upon a new agreement for the period 2010 until 2013.

2 However, the government has few initiatives specially directed toward older workers, except from an advisory service on old age policies. Actual old age policy measures must to a large degree be financed to a large degree by the firms themselves.

3 From 2011, we will have an arrangement with a flexible retirement age under the National Insurance Scheme from the age of 62; with the pension benefit being higher the longer one waits before drawing it. From the same age, a person may continue working and still draw a pension from the National Insurance Scheme, without the pension being affected.

${ }^{4}$ In addition, about $40 \%$ of local governmental employees have an age limit of 65 - for example, nurses, auxiliary nurses, home carers, cleaners, and drivers. According to the socalled " 85 -years rule," they are also allowed to leave their position up to 3 years before this age limit and get their occupational pension, if their age and years in public service in sum equals 85 years or more. 
5 From 2004, employers in local governmental sector could also choose to opt out of a common redistribution system in which the collective carries the AFP-cost, and carry 50 or $100 \%$ of the total costs of their own AFP-pensioners themselves.

${ }^{6}$ In 2012, we had the possibility to revisit the six municipalities from the 2006/2007-study in order to see the outcomes of their old age policy, whether it had fulfilled its promises in reducing early retirement, and if not what obstacles they had met. At this last visit, we interviewed the same type of informants as at the former visit.

7 Norway has 431 municipalities that differ on a wide range of conditions such as the size of the population (number of inhabitants), economic situation, demography, recruitment conditions, and so on. Within the governmental system, the municipalities are allowed self-determination on a wide number of questions.

8 Two of these were also part of the former mention study. We chose to revisit these two since we then had the possibility to do a follow-up. In the 2009-2010 study, the number of new cases was thus six.

9 Originally, there were 14 cases, but two of these "overlapped."

10 The interview guides are documented in Midtsundstad \& Bogen (2011) and Bogen \& Midtsundstad (2007).

11 See earlier note. 